EDITORIAL, v. 21, n. 41 (Dezembro, 2017)

EDITORIAL, v. 21, n. 41 (Diciembre, 2017)

EDITORIAL, v. 21, n. 41 (December, 2017)

Carla GORNI ${ }^{1}$

Desde 1996, a Revista Científica do Centro Universitário de Barra Mansa, sob o ISSN $n^{\circ} 1516-4017$ é periódico interdisciplinar com foco em publicar artigos sobre ciência da forma mais exigente e precisa possível.

A proposta fundamental de acolher e divulgar conhecimento de áreas Humana, Exata, Biológica e Arte é um grande desafio. Qualidade intelectual e rigor científico são nossas premissas editoriais, em grande parte, asseguradas pela equipe de avalistas, membros de conselho e equipe editorial, bases indexadoras e pela assessoria de editores da ABEC, Associação Brasileira de Editores Científicos.

Os avalistas somam 28 professores doutores ou pos doutores nas 4 áreas supracitadas; todos pesquisadores e docentes ativos em Instituições de Ensino Superior espalhadas por cinco estados brasileiros (Rio de Janeiro, São Paulo, Minas Gerais, Alagoas e Paraíba). Os Membros do Conselho Editorial têm colaborado sugerindo estratégias que nos encaminham às proposições apresentadas, promovendo melhoras constantes e ações que estão, aos poucos, tornando esta publicação online meritória de atenção nacional e internacional. Os profissionais de editoração-editora, coeditor, editor de layout e editora de texto - trabalham, em conjunto, de forma circular complementar, captando artigos, os encaminhando à avalistas, enviando solicitações de correções aos autores, recolhendo os artigos já corrigidos, os organizando, revisando gramaticalmente, diagramando e fazendo a última inspeção da arte. Sem hierarquizar axiologicamente, esses profissionais empenhados, são responsáveis pela essência e pela aparência da Revista Científica do UBM. As bases de indexação também acabam dando aval de qualidade aos artigos aqui publicados.

\footnotetext{
${ }^{1}$ Centro Universitário de Barra Mansa (UBM), Barra Mansa - RJ - Brasil. Doutora em Música, PPGM-UNIRIO - Brasil.

Coordenadora e Docente do Curso de Licenciatura em Música do UBM

Orientadora de Pesquisa, Grupo Pesquisa em Música UBM

Editora Chefe da Revista Científica do UBM

ORCID: https://orcid.org/0000-0001-9085-1631

E-mail: carla.gorni@ sobeu.edu.br
} 
Para este número, a assessoria dos editores ligados à Abec foi prestativa e pontual. A relação começou no Curso de Editoração Científica, em São Paulo, em junho de 2017, o que facilitou a dissolução de dúvidas e promoveu tratamento efetuoso de questões editoriais.

Na Edição passada, o trigésimo sexto número, em agosto de 2017, o periódico de 261 páginas conta com quinze artigos que abordam direito(2), educação(2), sociologia (1), psicología (1), gestão ambiental (1), microbiologia (1), química (1), medicina veterinária (2), nutrição (1), educação física (1) e música (2). Já esta, graças ao professor e doutorando José Anderson Santos Cruz, Secretário Executivo/Assistente Editorial da Revista Ibero Americana de Estudos em Educação, da UNESP - a quem agradeço o comprometido e a gentileza, nosso periódico cede espaço expressivo à área de educação (6 artigos), além de e trazer compilação de resumos expandidos(4) provenientes da XXI Jornada de Medicina Veterinária - JOMEV, dos dias 25 a 29 de setembro de 2017, no Centro Universitário de Barra Mansa. A edição inclui textos de direito (3), música (2), medicina veterinária (2), microbiologia (1), química (1), sociologia (1) e ciências contábeis (1).

Esta equipe editorial, então concluindo seu trabalho em 2017, lançou 33 artigos, 5 internos e 28 externos. Além disso, a área de Arte, que antes de 2016 não contava com nenhuma publicação, ganhou espaço na revista tendo 7 artigos publicados de 2016.2 a 2017.2.

Terminamos 2017 gratos aos autores por nos confiarem a publicação seus textos. Boa leitura a todos!

\section{Carla Gorni}

Editora 